\title{
Sertifikasi untuk Meningkatkan Profesionalisme Guru
}

\author{
Yopa Taufik Saleh \\ Universitas Muhammadiyah Tasikmalaya \\ E-mail :yopa_4474@yahoo.co.id
}

\begin{abstract}
The low quality of education in Indonesia cannot be separated from the low quality of teachers. To achieve qualified teachers, so it needs the effective of teacher management start from the appointment, the placement, the induction, the welfare, and the teacher professional development. The certification program is one of government programs to increase the teachers' professionalism. However, this certification program was responded vary by teachers. Some of them respond it with sincerity and other consider it just as other policies. Meanwhile, the teacher certification could be interpreted as the government's efforts in providing education certificates to the teachers and lecturers who have met certain requirements, including academic qualifications, competence, professional in the field of education with the aim to increase learning motivation and teachers' welfare. Certification is a government program in increasing the teachers' motivation and professionalism. Thus, it is expected to be able to solve any problems in education world.
\end{abstract}

Keywords: Certification, Motivation, Professional

\section{Pendahuluan}

$\mathrm{S}$ alah satu tujuan guru sebagai tenaga pendidik di Indonesia adalah untuk mencerdaskan kehidupan bangsa. Kinerja guru selama ini telah menjadi wacana dalam meningkatkan mutu Sumber Daya Manusia (SDM) kependidikan. Persoalan guru adalah persoalan pendidikan, dan persoalan pendidikan adalah persoalan bangsa. Sedangkan menurut UU Sisdiknas No.20 Tahun 2003 pendidikan merupakan usaha sadar dan terencana untuk mewujudkan suasana belajar dan proses pembelajaran agar peserta didik secara aktif mengembangkan potensi dirinya untuk memiliki kekuatan spiritual keagamaan, pengendalian diri, kepribadian, kecerdasan, akhlak mulia, serta keterampilan yang diperlukan dirinya, masyarakat, bangsa dan negara.

Dalam proses pembelajaran di sekolah, pendidik atau guru merupakan tenaga profesional yang bertugas merencanakan dan melaksanakan proses pembelajaran, menilai hasil pembelajaran, melakukan pembimbingan dan pelatihan, serta melakukan penelitian dan pengabdian kepada masyarakat, terutama bagi pendidik pada perguruan tinggi. Layanan pendidikan di sekolah diarahkan untuk memfasilitasi perkembangan potensi peserta didik secara optimal. Pendidikan yang berkualitas hanya akan dapat diwujudkan jika tersedia guru yang berkualitas.

Penentu kualitas pendidikan di Indonesia, tidak terlepas dari kualitas profesionalisme guru. Menurut Riyanto (2008:14) profesional atau tidaknya profesi guru tergantung pada faktor profesional atau tidaknya model pendidikan guru, baik guru pada tingkat pendidikan anak usia dini (PAUD), pendidikan dasar, maupun pendidikan menengah, bahkan dalam beberapa hal pada tingkat pendidikan tinggi. Sementara itu, untuk mewujudkan guru yang berkualitas diperlukan manajemen guru yang efektif mulai dari pengangkatan, penempatan, induksi, kesejahteraan, dan pengembangan profesi guru. 
Guru yang berkualitas dipengaruhi oleh banyak faktor diantaranya adalah kualitas calon guru yang masuk di Lembaga Pendidikan Tenaga Kependidikan (LPTK), proses pendidikan di LPTK, dan manajemen guru yang diterapkan. Serta masalah kesejahteraan yang menjadi penunjang profesionalisme guru.

Berbagai upaya peningkatan kualitas guru telah dilakukan. Seperti peningkatan kemampuan/penguasaan tentang berbagai macam strategi ataupun metode pembelajaran melalui berbagai kegiatan (workshop, diklat, dsb), dan salah satu upaya peningkatan kualitas guru adalah melalui program sertifikasi guru.

Setelah dikeluarkannya Undang-Undang nomor 14 Tahun 2005 tentang Guru dan Dosen, istilah sertifikasi menjadi istilah yang sangat popular dan menjadi topik pembicaraan di dunia pendidikan. Program sertifikasi yang merupakan salah satu program pemerintah untuk menunjang profesionalisme guru tercantum dalam Permendiknas Nomor 18 Tahun 2007 tentang Sertifikasi Guru Dalam Jabatan, 4 Mei 2007, dan keputusan Mendiknas Nomor 057/0/2007 tentang Penetapan Perguruan Tinggi Penyelenggara Sertifikasi Guru Dalam Jabatan, 13 Juli 2007. Hal ini sejalan dengan Muslich (2007) yang berpendapat bahwa terdapat tiga fungsi diberlakukannya undang-undang tersebut, pertama, sebagai landasan yuridis bagi guru dari perbuatan semena-mena dari siswa, orang tua dan masyarakat; kedua, untuk meningkatkan profesionalisme guru; ketiga, untuk meningkatkan kesejahteraan guru.

Sertifikasi guru merupakan program yang menjanjikan bagi guru. Selain pemerintah bermaksud ingin meningkatkan profesionalisme guru, juga ingin meningkatkan taraf hidup guru (Mukhtar, 2011). Sehingga tugas utama guru dalam mencerdaskan kehidupan bangsa bisa terlaksana sesuai dengan target capaian yang diharapkan, selain itu taraf hidup guru di Indonesia diharapkan akan lebih meningkat.

Namun program sertifikasi guru tersebut yang sejatinya adalah untuk meningkatkan kompetensi guru ternyata tidak sesuai dengan yang diharapkan, guru yang telah lolos sertifikasi ternyata tidak menunjukkan kompetensi yang signifikan (Kompas, 13 November 2009). Banyak oknum-oknum yang tidak bertanggung jawab. Dimana untuk mendapatkan sertifikasi akhirnya menghalalkan segala cara karena program sertifikasi tersebut dianggap sangat menjanjikan. Menurut Prof. Dr. Baedhowi, dalam pidato pengukuhan guru besar di FKIP Universitas Sebelas Maret Solo, memaparkan kajiannya, bahwa motivasi para guru mengikuti sertifikasi umumnya terkait aspek finansial, yaitu segera mendapat tunjangan profesi (Kompas, 13 November 2009). Sehingga rencana pemerintah dalam meningkatkan profesionalisme guru harus terhambat karena secara umum motivasi guru untuk mengikuti sertifikasi adalah terkait finansial. Akibatnya meski telah dinyatakan lulus sertifikasi dan telah menerima tunjangan profesi, tidak menjamin telah memiliki kompetensi yang dipersyaratkan oleh undang-undang.

\section{Sertifikasi}

\section{a. Pengertian}

Sertifikasi merupakan program pemerintah untuk meningkatkan profesionalisme guru di Indonesia. Terdapat beberapa pasal yang tertuang di dalam Undang-Undang RI Nomor 14 Tahun 2005 tentang Guru dan Dosen mengenai sertifikasi diantaranya:

1) Pasal 1 butir 11: Sertifikasi adalah proses pemberian sertifikat pendidik kepada guru dan dosen.

2) Pasal 8: Guru wajib memiliki kualifikasi akademik, kompetensi, sertifikat pendidik, sehat jasmani dan rohani, serta memiliki kemampuan untuk mewujudkan tujuan pendidikan nasional.

3) Pasal 11 butir 1: Sertifikat pendidik sebagaimana dalam pasal 8 diberikan kepada guru yang telah memenuhi persyaratan.

4) Pasal 16: Guru yang memiliki sertifikat pendidik memperoleh tunjangan profesi sebesar satu kali gaji, guru negeri maupun swasta dibayar pemerintah. 
Undang-Undang RI Nomor 14 Tahun 2005 tentang Guru dan Dosen tersebut menjelaskan bahwa sertifikasi adalah proses pemberian sertifikat pendidik kepada guru dan dosen yang telah memenuhi persyaratan dan guru yang memiliki sertifikat pendidik memperoleh tunjangan profesi sebesar satu kali gaji yang dibayar oleh pemerintah. Sementara itu sertifikat pendidik adalah bukti formal sebagai pengakuan yang diberikan kepada guru dan dosen sebagai tenaga pendidik professional.

Menurut National Commission on Educational Services (NCES), sertification is a procedure whereby the state evaluates and review a teacher candidate's credentials and provides him or her a license to teach (sertifikasi adalah prosedur untuk menentukan apakah seorang calon guru layak diberikan izin dan kewenangan untuk mengajar). Hal ini sejalan dengan Mulyasa (2007) yang mengartikan sertifikasi sebagai proses uji kompetensi yang dirancang untuk mengungkapkan penguasaan kompetensi seseorang sebagai landasan pemberian sertifikat pendidik. Sedangkan Kunandar (2009) menyatakan bahwa sertifikasi profesi guru adalah proses untuk memberikan sertifikat kepada guru yang telah memenuhi standar kualifikasi dan standar kompetensi.

Dari beberapa pengertian mengenai sertifikasi di atas, maka sertifikasi bisa diartikan sebagai upaya pemerintah dalam memberikan sertifikat pendidikan kepada guru dan dosen yang telah memenuhi persyaratan tertentu, diantaranya memiliki kualifikasi akademik, kompetensi, sertifikat pendidik, sehat jasmani dan rohani, serta memiliki kemampuan untuk mewujudkan tujuan pendidikan nasional, profesional di bidang pendidikan dengan tujuan untuk meningkatkan motivasi mengajar serta kesejahteraan bagi guru sehingga tujuan utama guru untuk mencerdaskan kehidupan bangsa bisa tercapai.

\section{b. Manfaat dan Tujuan Sertifikasi}

Tujuan sertifikasi sebagai program pemerintah yaitu salah satunya untuk meningkatkan mutu pendidikan. Menurut
Wibowo (dalam Mulyasa, 2007), mengungkapkan bahwa sertifikasi guru bertujuan untuk hal-hal sebagai berikut:

1) Melindungi profesi pendidik dan tenaga kependidikan.

2) Melindungi masyarakat dari praktekpraktek yang tidak kompeten, sehingga merusak citra pendidik dan tenaga kependidikan.

3) Membantu dan melindungi lembaga penyelenggara pendidikan, dengan menyediakan rambu-rambu dan instrumen untuk melakukan seleksi terhadap pelamar yang kompeten.

4) Membangun citra masyarakat terhadap profesi pendidik dan tenaga kependidikan.

5) Memberikan solusi dalam rangka meningkatkan mutu pendidik dan tenaga kependidikan.

Sudjanto (2009), mengungkapkan bahwa manfaat sertifikasi guru adalah sebagai berikut:

1) Melindungi profesi guru dari praktikpraktik yang tidak kompeten, yang dapat merusak citra profesi guru.

2) Melindungi masyarakat dari praktik-praktik pendidikan yang tidak berkualitas dan tidak profesional.

3) Menjaga lembaga penyelenggara pendidikan tenaga kependidikan (LPTK) dari keinginan internal dan tekanan eksternal yang menyimpang dari ketentuanketentuan yang berlaku.

Lebih lanjut dikemukakan tentang manfaat sertifikasi tenaga kependidkan yaitu meliputi pengawasan mutu dan penjaminan mutu. Dimana pengawasan mutu pendidikan dilakukan melalui mekanisme dan proses seleksi yang baik seperti program pelatihan yang bermutu maupun usaha belajar mandiri dengan tujuan untuk mencapai peningkatan profesionalisme tenaga pendidik. Sedangkan penjaminan mutu yang merupakan manfaat sertifikasi yaitu untuk memberikan jaminan atau perlindungan profesi bagi guru yang telah di sertifikasi. 


\section{c. Perlunya Guru Disertifikasi}

Pemerintah Indonesia sebenarnya sudah mengisyaratkan akan memberlakukan sertifikasi bagi guru, sebagaimana yang telah tertuang dalam Undang-Undang Nomor 25 Tahun 2000 tentang program pembangunan nasional yang berisi pembentukan badan akreditasi dan sertifikasi mengajar di daerah. Undang-Undang tersebut dikeluarkan dengan tujuan meningkatkan kualitas tenaga kependidikan secara nasional.

Dalam Undang-Undang Republik Indonesia Nomor 14 Tahun 2005 tentang Guru dan Dosen pada pasal 8 dan pasal 11 ayat (1), dimana dalam pasal 8 dijelaskna bahwa guru wajib memiliki kualifikasi akademik, kompetensi, sertifikat pendidik, sehat jasmani dan rohani, serta memiliki kemampuan untuk mewujudkan tujuan pendidikan nasional serta dalam pasal 11 ayat (1) dijelaskan bahwa sertifikat pendidik sebagaimana dimaksud dalam pasal 8 diberikan kepada guru yang telah memenuhi persyaratan, ayat (2) Sertifikasi pendidik diselenggarakan oleh perguruan tinggi yang memiliki program pengadaan tenaga kependidikan yang terakreditasi dan ditetapkan oleh Pemerintah, ayat (3) Sertifikasi pendidik dilaksanakan secara objektif, transparan, dan akuntabel, ayat (4) Ketentuan lebih lanjut mengenai sertifikasi pendidik sebagaimana dimaksud pada ayat (2) dan ayat (3) diatur dengan Peraturan Pemerintah.

Lebih lanjut menurut dalam UndangUndang Republik Indonesia Nomor 20 tahun 2003 Tentang Sistem Pendidikan Nasional Pasal 42 ayat (1) menjelaskan bahwa Pendidik harus memiliki kualifikasi minimum dan sertifikasi sesuai dengan jenjang kewenangan mengajar, sehat jasmani dan rohani, serta memiliki kemampuan untuk mewujudkan tujuan pendidikan nasional dan Pasal 43 ayat (2), yang berisi: sertifikasi pendidik diselenggarakan oleh perguruan tinggi yang memiliki program pengadaan tenaga kependidikan yang terakreditasi.

Vol. 1 No. 1, 2016
Sebagaimana tadi dijelaskan bahwa tujuan pemerintah memberlakukan sertifikasi bagi guru adalah tidak lain agar motivasi mengajar guru sebagai tenaga pendidik bisa meningkat yang pada akhirnya capaian pemerintah dalam meningkatkan kinerja guru bisa terlaksana. Selain itu, program sertifikasi ini sebagai bukti atau pengakuan atas kemampuan profesionalnya sebagai tenaga pendidik.

Masalah kesejahteraan yang menjadi penunjang profesionalisme guru pun tak luput dari perhatian pemerintah. Sehingga dengan adanya program sertifikasi ini pemerintah ingin memberikan reward berupa penghargaan/pemberian tunjangan profesional yang berlipat dari gaji yang diterima. Harapan kedepannya adalah tidak ada lagi guru yang bekerja mencari objekan di luar dinas karena kesejahteraannya sudah terpenuhi. Tapi apakah tujuannya hanya untuk meningkatkan kesejahteraan guru tanpa mengesampingkan profesionalitas guru dalam mengajar?

Secara formal, Undang-Undang RI Nomor 20 Tahun 2003 tentang Sistem Pendidikan Nasional, Undang-Undang RI Nomor 14 tahun 2005 tentang Guru dan Dosen, dan Peraturan Pemerintah Nomor 19 Tahun 2005 tentang Standar Nasional Pendidikan menyatakan bahwa guru adalah tenaga profesional.

Sebagai tenaga profesional, guru dipersyaratkan memiliki kualifikasi akademik S1 atau D4 dalam bidang yang relevan dengan mata pelajaran yang diampunya dan menguasai kompetensi sebagai agen pembelajaran.

\section{d. Pengertian dan Pentingnya Guru Profesional}

Istilah profesional berasal dari profession yang berarti pekerjaan. Profesionalisme adalah suatu tingkah laku, suatu tujuan atau rangkaian kualitas yang menandai atau melukiskan coraknya suatu profesi (the conduct, aims or qualities, that characterize a profession). Profesionalisme mengandung pengertian menjalankan suatu profesi untuk keuntungan atau sumber penghidupan (the following of $a$ profession for gain or livehood) (Anoraga, 2005). 
Sedangkan menurut Arifin dalam buku kapita Selekta Pendidikan mengatakan bahwa profession mengandung arti yang sama dengan kata occupation atau pekerjaan yang memerlukan keahlian yang diperoleh melalui pendidikan atau latihan khusus (1995)

Sudarwan Danim mengatakan bahwa tuntutan kehadiran guru yang profesional tidak pernah surut, karena dalam latar proses kemanusiaan dan pemanusiaan, ia hadir sebagai subjek paling diandalkan yang sering kali disebut Oemar Bakri (2003:191-192).

Dalam pendidikan, guru adalah seorang pendidik, pembimbing, pelatih, dan pemimpin yang dapat menciptakan iklim belajar yang menarik, memberi rasa aman, nyaman dan kondusif dalam kelas. Keberadaannya di tengahtengah siswa dapat mencairkan suasana kebekuan, kekakuan dan kejenuhan belajar yang terasa berat diterima oleh para siswa. Kondisi seperti itu ternyata memerlukan keterampilan dari seorang guru, dan tidak semua mampu melakukannya. Menyadari hal itu, maka peneliti menganggap bahwa keberadaan guru profesional sangat diperlukan.

Guru yang profesional merupakan faktor penentu proses pendidikan yang bermutu. Untuk dapat menjadi guru profesional, mereka harus mampu menemukan jati diri dan mengaktualkan diri. Pemberian prioritas yang sangat rendah pada pembangunan pendidikan selama beberapa puluh tahun terakhir telah berdampak buruk yang sangat luas bagi kehidupan berbangsa dan bernegara (Sholeh, 2006: 9).

Untuk itu, guru diharapkan tidak hanya sebatas menjalankan profesinya, tetapi guru harus memiliki rasa keterpanggilan untuk melaksanakan tugasnya dengan melakukan perbaikan kualitas pelayanan terhadap peserta didik baik dari segi intelektual maupun kompetensi lainnya yang akan menunjang perbaikan dalam pelaksanaan kegiatan belajar mengajar.

\section{e. Kriteria dan Kemampuan yang Harus Dimiliki Guru Profesional}

Kinerja guru merupakan kemampuan yang ditunjukan oleh seorang guru dalam melaksanakan tugas dan pekerjaannya. Seorang guru yang professional harus mengetahui kriteria yang harus dimiliki guru profesional terkait dengan kinerja. Mangkunegara (2000) menyatakan bahwa kinerja (prestasi kerja) adalah hasil kerja secara kualitas dan kuantitas yang dicapai oleh seorang pegawai dalam melaksanakan tugasnya sesuai dengan tanggung jawab yang diberikan. Undang-Undang Guru dan Dosen Nomor 14 Tahun 2005 menyatakan bahwa Guru adalah pendidik profesional dengan tugas utama mendidik, mengajar, membimbing, mengarahkan, melatih, menilai, dan mengevaluasi peserta didik pada pendidikan anak usia dini jalur pendidikan formal, pendidikan dasar, dan pendidikan menengah.

Dalam kurikulum 2013 terdapat standar proses yang merupakan pengembangan dari standar proses kurikulum sebelumnya. Standar proses tersebut merupakan acuan bagi guru dalam proses pembelajaran di sekolah. Guru dipandang berhasil apabila mampu melaksanakan dan mengembangkan standar proses tersebut, sehingga pelaksanaan proses pembelajaran akan terlaksana sesua dengan yang diharapkan. Keberhasilan seorang guru akan terlihat apabila pembelajaran yang diberikannya mampu mengubah perilaku peserta didik kearah yang lebih baik.

Oleh karena itu, guru yang profesional harus memiliki kriteria-kriteria tertentu yang positif. Hamalik (2006) menuturkan beberapa persyaratan yang harus dimiliki guru professional, yaitu sebagai berikut:
a. Memiliki bakat sebagai guru;
b. Memiliki keahlian sebagai guru;
c. Memiliki keahlian yang baik dan terintegrasi;
d. Memiliki mental yang sehat;
e. Berbadan sehat;
f. Memiliki pengalaman dan pengetahuan yang luas; 
g. Guru adalah manusia berjiwa pancasila;

h. Guru adalah seorang warga yang baik.

Dikalangan pendidikan, guru dipandang sebagai sosok yang utuh apabila memiliki kompetensi profesional. Karenanya profesionalisme seorang guru sangat diperlukan. Kompetensi profesional guru terdiri atas beberapa kemampuan. Muslich (2007) menjelaskan beberapa kompetensi yang harus dimiliki guru professional yaitu sebagai berikut:

1) Mengenal secara mendalam peserta didik yang hendak dilayani

2) Menguasai bidang ilmu sumber bahan ajaran, baik dari segi, Substansi dan metodologi bidang ilmu (disciplinary content knowledge), maupun pengemasan bidang ilmu menjadi bahan ajar dalam kurikulum (pedagogical content knowledge).

3) Menyelenggarakan pembelajaran yang mendidik, mencakup:

b) Implementasi program pembelajaran termasuk penyesuaian sambil jalan (midcourse) berdasarkan on going transactionaldecision berhubungan dengan adjustments dan reaksi unik (idiosyncratic response) dari peserta didik terhadap tindakan guru;
c) Mengakses proses dan hasil pembelajaran;

d) Menggunakan hasil assesmen terhadap proses dan hasil pembelajaran dalam rangka perbaikan pengelolaan pembelajaran secara berkelanjutan.

4) Mengembangkan kemampuan profesional secara berkelanjutan.

Demikian juga Mulyasa (2002) mengatakan tugas guru yang paling utama adalah bagaimana mengkondisikan lingkungan belajar yang menyenangkan, agar dapat membangkitkan rasa ingin tahu semua peserta didik sehingga timbul minat dan nafsunya untuk belajar. Karena itu kondisi yang yaman baik secara fisik maupun psikis dapat menunjang profesionalisme guru.

Vol. 1 No. 1, 2016
Lebih lanjut Mulyasa (2008) menuturkan terdapat beberapa standar kompetensi yang harus dimiliki guru diantanya standar kompetensi mental, moral, spiritual, intelektual, fisik dan psikis. Kompetensi lainnya yang harus dimiliki guru mencakup kompetensi personal, kompetensi profesional, kompetensi akademik, dan kompetensi sosial.

Kompetensi personal meruapakan cerminan kepribadian guru dalam berprilaku. Kompetensi profesional merupakan penguasaan guru atas keterampilan-keterampilan yang berkaitan dengan tugas-tugas pekerjaan guru sebagai pendidik baik berupa penguasaan metode pembelajaran, penguasaan media pembelajaran, maupun penguasaan kurikulum pembelajaran. Kompetensi akademik berupa kemampuan guru dalam menguasai materi ajar sesuai dengan bidang keahliannya. Sedangkan kompetensi sosial berupa kemampuan guru dalam bersosialisasi dengan semua pihak baik di lingkungan pendidikan maupun masyarakat luas.

Guru profesional harus mempunyai kompetensi yang dipersyaratkan guna melaksanakan profesinya agar mencapai hasil yang memuaskan. Kompetensi-kompetensi yang dipersyaratkan itu dipandang sebagai bagian atau komponen yang tidak terpisahkan dari eksistensi guru dalam melaksanakan profesinya.

\section{f. Faktor-Faktor yang Mempengaruhi Profesionalisme Guru}

Kinerja atau prestasi kerja merupakan hasil kerja secara kualitas dan kuantitas yang dicapai oleh seorang pegawai dalam melaksanakan tugasnya sesuai dengan tanggung jawab yang diberikan. Hasil kerja yang baik tak lepas dari beberapa faktor yang mempengaruhinya. Kondisi yang nyaman baik fisik maupun psikis dapat mempengaruhi dan menunjang faktor profesionalisme guru. Ada beberapa faktor yang mempengaruhi produktivitas kerja seseorang, diantaranya: pekerjaan yang menarik, upah yang baik, keamanan dan perlindungan dalam pekerjaan, penghayatan atas maksud dan makna pekerjaan, lingkungan kerja, promosi dan perkembangan diri, keterlibatan dalam berbagai

ISSN : 2528-2921 
kegiatan, disiplin kerja yang keras. Hal ini sejalan dengan (Risma \& Sukanti (2012) yang menyatakan bahwa faktor-faktor yang mempengaruhi kinerja guru adalah :

1) Faktor personal atau indvidual, meliputi unsur pengetahuan, keterampilan, kemampuan, kepercayaan diri, motivasi dan komitmen yang dimiliki oleh tiap individu guru;

2) Faktor kepemimpinan, memiliki aspek kualitas manajer dan tim leader dalam memberikan dorongan, semangat, arahan,dan dukungan kerja kepada guru;

3) Faktor tim, meliputi dukungan dan semangat yang diberikan oleh rekan dalam satu tim, kepercayaan terhadap sesama anggota tim, kekompakan dan keeratan anggota tim,

4) Faktor sistem, meliputi sistem kerja, fasilitas kerja yang diberikan oleh pimpinan sekolah, proses organisasi (sekolah) dan kultur kerja dalam organisasi (sekolah),

5) Faktor kontekstual (situasional), meliputi tekanan dan perubahan lingkungan eksternal (sertifikasi guru) dan internal (motivasi kerja guru).

Kinerja guru yang ditunjukkan dapat diamati dari kemampuan guru dalam melaksanakan tugas dan tanggung jawab yang tentunya sudah dapat mencerminkan suatu pola kerja yang dapat meningkatkan mutu pendidikan kearah yang lebih baik. Seorang guru akan bekerja secara profesional bilamana memiliki kemampuan kerja yang tinggi dan kesungguhan hati untuk mengerjakan dengan sebaik-baiknya.

Sementara itu, menurut Alimuddin, ada beberapa faktor yang dapat mempengaruhi profasionalisme guru dalam mengajar, yaitu sebagai berikut:

a. Status Akademik

Pekerjaan guru adalah pekerjaan yang bersifat profesi, secara sederhana pekerjaan yang bersifat profesi adalah pekerjaan yang hanya dilakukan oleh mereka yang secara khusus disiapkan untuk itu dan bukan untuk pekerjaan lainnya. b. Pengalaman Belajar

Dalam menghadapi peserta didik, tidak mudah untuk mengorganisir mereka, hal tersebut banyak menjadi keluhan, serta banyak pula dijumpai guru yang mengeluh karena sulit untuk menciptakan suasana kegiatan belajar mengajar yang menyenangkan dan menggairahkan. Ini dikarenakan guru kurang mampu untuk menguasai dan menyesuaikan diri terhadap proses belajar mengajar yang berlangsung.

c. Mencintai Profesi Sebagai Guru

Rasa cinta akan mendorong individu untuk melakukan sesuatu sebagai usaha dan pengorbanan. Seseorang yang melakukan sesuatu dengan tanpa adanya rasa cinta, biasanya orang tersebut akan melakukannya dalam keadaan terpaksa. Dalam melakukan sesuatu akan lebih berhasil apabila disertai dengan adanya rasa mencintai terhadap apa yang dilakukannya itu.

d. Berkepribadian

e. Secara bahasa, kepribadian adalah keseluruhan sifat-sifat yang merupakan watak seseorang. Dalam proses belajar mengajar, kepribadian seorang guru ikut serta menentukan watak siswanya.

\section{g. Pengaruh Sertifikasi terhadap Profesionalisme Guru}

Sertifikasi merupakan proses pemberian sertifikat pendidik kepada guru. Sertifikat pendidik ini diberikan kepada guru yang memenuhi standar profesional guru. Standar profesional guru tercermin dari uji kompetensi. Uji kompetensi dilaksanakan dalam bentuk penilaian portofolio dan Pendidikan dan Pelatihan Profesi Guru. Pendidikan dan pelatihan profesi guru diakhiri dengan ujian yang mencakup empat kemampuan atau kompetensi yang harus dimiliki oleh guru yaitu kompetensi pedagogik, kompetensi kepribadian, kompetensi sosial, dan kompetensi professional.

Program sertifikasi merupakan program pemerintah yang salah satu tujuannya adalah untuk meningkatkan kepuasan kerja bagi para guru. Karena menurut Anogara (2005) kepuasan 
kerja merupakan sikap yang positif yang menyangkut penyesuaian diri yang sehat dari para pekerja terhadap kondisi dan situasi kerja, termasuk didalamnya masalah gaji, kondisi sosial, kondisi fisik dan psikologis.

Dampak lain dari program sertifikasi guru yaitu harapan peningkatan dalam beberapa aspek terutama aspek kedisiplinan kerja dan aspek kedisiplinan administratif akademik. Seperti perubahan disiplin dalam mengajar, aktif mengikuti berbagai kegiatan akademik di sekolah, pembimbingan siswa, serta aktif dalam kegiatan pembimbingan ekstrakulikuler. Selain itu kedisiplinan administratif akademik pun tak luput dari capaian harapan di dunia pendidikan, seperti memperhatikan perancangan skenario pembelajaran, mengupayakan media pembelajaran, mengisi daftar hadir kerja, serta pengembangan sistem evaluasi.

Sementara itu para guru yang telah disertifikasi harus menyadari menyadari bahwa era sekarang adalah era informasi dan teknologi, sehingga mereka perlu belajar terus menerus agar dapat menyesuaikan diri dengan tuntutan perubahan dan perkembangan zaman, terutama perkembangan dalam bidang ilmu dan pendidikan. Dengan mengikuti diklat sertifikasi, maka guru akan banyak mendapatkan ilmu baru guna meningkatkan kemampuan atau kompetensinya tersebut. Dan pada gilirannya, ilmu yang mereka dapatkan akan diterapkan di sekolah atau di kelas.

Dengan adanya sertifikasi, diharapkan kompetensi guru sebagai agen pembelajaran akan meningkat sesuai dengan standar yang telah ditetapkan. Dengan kompetensi guru yang memenuhi standar minimal, maka kinerja guru dalam mengelola proses pembelajaran dapat meningkat. Kualitas pembelajaran yang meningkat akan bermuara akhir pada terjadinya peningkatan prestasi hasil belajar siswa. Dampak sertifikasi terhadap perilaku ekonomi terutama kehidupan perekonomian para guru yang telah mendapatkan sertifikat pendidik diharapkan adanya perubahan kualitas hidup. Kualitas hidup yang baik dapat mendorong guru agar mampu

Vol. 1 No. 1, 2016 memecahkan masalah-masalah pembelajaran yang dihadapi.

Selain mendapatkan sertifikat pendidik, guru yang telah lulus sertifikasi juga akan mendapatkan tunjangan profesi sebesar satu kali gaji pokok. Salah satu alat motivasi yang dapat digunakan untuk memotivasi seseorang adalah alat motivasi yang berupa materiil (uang dan barang) dan non materiil (medali/piagam). Para guru yang telah mendapatkan tunjangan profesi diharapkan mampu menyisihkan anggaran untuk peningkatan profesionalisme kerjanya, seperti membeli laptop, mengikuti seminar, workshop, membeli buku penunjang pelajaran, membeli buku dan belajar power point. Semua itu dilakukan dengan penuh kesadaran diri akan pentingnya peningkatan kualitas diri setelah mereka menerima tunjangan profesi. Dengan demikian, dengan adanya pemberian sertifikat profesi disertai tunjangan profesi bagi guru yang telah lulus program sertifikasi guru, akan meningkatkan motivasi kerja pada diri guru tersebut. Sehingga dapat dikatakan bahwa program sertifikasi profesi guru yang diadakan oleh pemerintah akan berpengaruh terhadap motivasi kerja guru. Yang pada akhirnya akan meningkatkan profesionalisme guru di dunia pendidikan.

\section{Simpulan}

Dengan adanya sertifikasi diharapkan dapat meningkatkan kemampuan guru dalam melaksanakan tugasnya sebagai tenaga pendidik dan pengajar yang didasarkan pada kecakapan dan kemampuannya dalam rangka pembinaan peserta didik untuk mencapai tujuan pembelajaran yang ingin dicapai serta meningkatkan kompetensi profesional guru. Dampak sertifikasi terhadap kinerja para guru akup positif terhadap guru-guru yang memperoleh sertifikat pendidik, baik pada kedisiplinan kerja dan kedisiplinan administratif akademik. Pada sisi lain, program sertifikasi guru tertentu kurang berdampak terhadap kinerja para guru yang belum mendapatkannya. Para guru yang telah mendapatkan tunjangan profesi diharapakn mampu menyisihkan anggaran untuk 
peningkatan profesionalisme kerjanya, seperti membeli laptop, mengikuti seminar, workshop, membeli buku penunjang pelajaran, membeli buku dan belajar power point. Dalam kehidupan perekonomian para guru yang telah mendapatkan sertifikat pendidik jelas harus ada perubahan kualitas hidup, namun perubahan tersebut masih dalam batas kewajaran. Selain itu, program sertifikasi tersebut dapat meningkatkan kesejahteraan bagi guru di Indonesia sehingga akan meningkatkan motivasi dalam proses pembelajaran yang sesuai dengan harapan kualitas tenaga kependidikan secara nasional.

\section{Daftar Pustaka}

Anoraga, Pandji. (2005). Psikologi kerja. Jakarta : Rineka Cipta

Fasli, J. (2007). Sertifikasi Guru untuk Mennjudkan Pendidikan yang Bermutu. Surabaya: Kencana.

Hamalik, Oemar. (2006). Pendidikan Guru Berdasarkan Pendekatan Kompetensi. PT. Bumi Aksara, Jakarta.

Keputusan Menteri Pendidikan Nasional Republik Indonesia Nomor 057/O/2007 tentang Penetapan Perguruan Tinggi Penyelenggara Sertifikasi Bagi Guru Dalam Jabatan.

Kunandar. (2007). Guru Profesional Implementasi Kurikulum Tingkat Satuan Pembelajaran (KTSP) dan Sukses dalam Sertifikasi Guru. Jakarta: PT.Rajawali Pers.

Mukhtar, A.D. (2011). Pengarub Sertifikasi Terhadap Profesionalisme Guru-Guru di SMA Muhammadiyah Yogyakarta. Yogyakarta: UMY

Mulyasa, E. (2008). Standar Kompetensi dan Sertifikasi Guru. Bandung: PT.Remaja Rosda Karya.

Mulyasa. E. (2002). Kurikulum Berbasis Kompetensi, Konsep, Karakteristik dan Implementasi. PT Remaja Rosdakarya, Bandung.

Muslich, Mansur. (2007). Sertifikasi Guru Menuju Profesionalisme Pendidikan. Jakarta: PT Bumi Aksara.

Riyanto, Astim. (2008). Pendidikan Profesi Guru Indonesia dari Perspektif Hukum. Mimbar Pendidikan: Jurnal Kependidikan. Bandung: UPI Press.

Sholeh, Asrorun Ni'am. (2006). Membangun Profesionalitas Guru Analisis Kronologis atas Labirnya UndangUndang Guru dan Dosen. eLSAS, Jakarta.

Sudjanto, B. (2009). Cara Efektif Menuju Sertifikasi Guru. Jakarta: RAS

Undang-Undang Republik Indonesia Nomor 14 Tahun 2005 tentang Guru dan Dosen.

Undang-Undang Republik Indonesia Nomor 14 Tahun 2005 tentang Guru dan Dosen.

Undang-Undang Republik Indonesia Nomor 20 Tahun 2003 tentang Sistem Pendidikan Nasional. Undang-Undang Republik Indonesia Nomor 20 Tahun 2003 tentang Sistem Pendidikan Nasional. 